\title{
High rates of agricultural gypsum affect the arbuscular mycorrhiza fungal community and coffee yield
}

\author{
Franciane Diniz $\operatorname{Cogo}^{1}$ (D), Orivaldo José Saggin Júnior² (D), Paulo Tácito Gontijo Guimarães (D), \\ José Oswaldo Siqueira ${ }^{(\mathbb{D}}$, Marco Aurélio Carbone Carneiro $4, \star$ (D) \\ 1. Universidade do Estado de Minas Gerais - Unidade Acadêmica de Passos - Passos (MG), Brazil. \\ 2. Empresa Brasileira de Pesquisa Agropecuária - Centro Nacional de Pesquisa de Agrobiologia - Laboratório de \\ Micorriza - Seropédica (RJ), Brazil. \\ 3. Empresa de Pesquisa Agropecuária de Minas Gerais - Belo Horizonte (MG), Brazil. \\ 4. Universidade Federal de Lavras - Departamento de Ciência do Solo - Lavras (MG), Brazil.
}

\begin{abstract}
High rates of agricultural gypsum, above the recommended levels, have been used on a regular basis to deepen plant roots and to alleviate recurrent water stress in Cerrado areas. However, very little is known about the consequences of this practice to arbuscular mycorrhizal fungi (AMF). Therefore, the objective of this study was to evaluate whether or not applying high rates of agricultural gypsum affects the mycorrhizal fungi community, glomalin content and coffee yield. The study rates were: $0 ; 3.5 ; 7.0 ; 14$ and $56 \mathrm{t} \cdot \mathrm{ha}^{-1}$ of agricultural gypsum applied in the planting row of the coffee plantation on top of the previous recommended gypsum application. Samples were collected for analysis at the depths of 0-20, 20-40 and 40-60 cm at the end of dry and rainy seasons of the year. In the coffee plantation, 16 AMF species were identified. Gigaspora sp. and Glomus macrocarpum were dominant in all situations. The rate of $7 \mathrm{t} \cdot \mathrm{ha} \mathrm{a}^{-1}$ favored greater diversity of AMF species and the rate of $56 \mathrm{t} \cdot \mathrm{ha}^{-1}$ reduced AMF diversity and mycorrhizal colonization in deeper layers. In the rainy season, there was a linear decrease of easily extractable glomalin-related soil protein (EE-GRSP) levels as the agricultural gypsum rate was increased. Coffee yield was reduced with the highest gypsum rate (56 tha $\left.\mathrm{a}^{-1}\right)$, even though the coffee plantation had higher phosphorus contents in beans and leaves. This may have resulted from a number of reasons, including a negative effect on the AMF community.

Key words: Coffea arabica L., Glomalin, Gypsum, Cerrado.
\end{abstract}

\author{
Received: \\ Jan. 13, 2020

\section{Accepted:} \\ Aug. 18, 2020 \\ Section Editor: \\ Hector Valenzuela \\ ${ }^{\star}$ Corresponding author: \\ marcocarbone@ufla.br
}

\section{INTRODUCTION}

The soils of the Cerrado biome extend over about $22 \%$ of the Brazilian territory (more than 2 million $\mathrm{km}^{2}$ ). In their natural condition, they are characterized by high acidity, low fertility, high P adsorption and seasonal water deficit (Lopes and Cox 1977). As a result of agribusiness development in the Cerrado and improved techniques for neutralization of subsoil acidity, gypsum application has become a common practice to increase coffee bean yield (Serafim et al. 2011). It is known that the application of agricultural gypsum brings several benefits, namely, increased concentration of $\mathrm{Ca}^{2+}$ in the soil solution (Ramos et al. 2013), more even distribution of roots (Carducci et al. 2015) and, consequently, reduced water deficit of the crops (Silva et al. 2014).

The recommended amount of gypsum can be defined on the basis of soil texture, residual $\mathrm{P}$ or $\mathrm{Al}^{+3}, \mathrm{Ca}^{+2}$ and $\mathrm{Mg}^{+2}$ levels (Guimarães et al. 1999). Because of the annual dry season, farmers tend to apply high rates of agricultural gypsum (above the recommended rate) to coffee crops to improve the root environment in deep subsoil and mitigate water stress in plants 
(Silva et al. 2014). However, applying high rates of agricultural gypsum can affect the chemical, physical and biological properties of the soil, for example, the arbuscular mycorrhizal fungi (AMF) community.

Arbuscular mycorrhizal fungi are obligate biotrophic symbionts of widespread occurrence in soils with coffee plantations (Arias et al. 2012). Previous research has shown that coffee plants are extremely dependent on such symbiosis (Saggin Júnior and Siqueira 1996), which increases their tolerance to fungal pathogens, nematodes (Alban et al. 2013), water deficit (Moreira et al. 2018) and weeds (França et al. 2016) and improves their intake of nutrients (Saggin Júnior et al. 1994), especially phosphorus (Siqueira et al. 1998). In addition to these direct benefits to coffee plants, AMF species play a role in soil structure through their extraradical hyphae and production of a protein in the mycorrhizal fungal cell walls, called glomalin (Carneiro et al. 2015).

Crop management changes the composition and diversity of AMF communities present in coffee plantations, both qualitatively and quantitatively (Arias et al. 2012). Moreover, application of agricultural gypsum to coffee plants in the Cerrado has become essential, and coffee is highly dependent on AMF species. Therefore, application of high rates of agricultural gypsum in coffee plantations needs to be evaluated for changes to AMF communities and the consequent effect on their functions.

Thus, the objective of this work was to evaluate whether or not the application of high rates of agricultural gypsum, above the level recommended for coffee crops, affects the arbuscular mycorrhizal fungi community, glomalin content and coffee yield.

\section{MATERIAL AND METHODS}

The experiment was set up on the farm Fazenda AP Familia, in the city of São Roque de Minas, MG ( $\left.20^{\circ} 15^{\prime} 45.00^{\prime \prime} \mathrm{S}, 46^{\circ} 18^{\prime} 17.00^{\prime \prime} \mathrm{W}\right)$, with average altitude of $850 \mathrm{~m}$. The climate of the region is Cwa, according to the Köppen-Geiger classification, with dry winters and hot and humid summers. The dry season is well-defined between the months of May and September. According to data from Climate-data.org (2019), average temperature is $20.6^{\circ} \mathrm{C}$ and average annual rainfall is $1390 \mathrm{~mm}$. January is the warmest month of the year (average temperature of $23^{\circ} \mathrm{C}$ ) while June is the coldest (average temperature of $17^{\circ} \mathrm{C}$ ). The rainiest month is December (average rainfall of $270 \mathrm{~mm}$ ) and the driest month is August (average rainfall of $11 \mathrm{~mm}$ ). The soil was classified as a typical dystrophic red latosol. It has a very clayey texture containing $660,290,50 \mathrm{~g} \cdot \mathrm{kg}^{-1} \mathrm{of}$ clay, silt and sand, respectively (Santos et al. 2006). Table 1 shows the chemical properties of the treatments.

The study used a slipt-plot randomized block design; the main plot consisted of agricultural gypsum rates and the subplots, of soil sampling depths. The experiment was arranged in a $5 \times 3$ factorial scheme ( 5 agricultural gypsum rates $\times 3$ sampling depths), with three replications. Gypsum rates were 0 (control); 3.5; 7; 14 and $56 \mathrm{t} \cdot \mathrm{ha}^{-1}$, and sampling depths were $0-20 ; 20-40$ and $40-60 \mathrm{~cm}$.

A native forest - near the experimental area and with the same soil class - was used as a reference. This forest was not included in the study design and was not used for comparison of means. It was used only to assess the effects of gypsum application and other crop growing practices in the native AMF community.

Coffee (Coffea arabica cultivar Catucaí) was planted in October 2008, with spacing of $2.5 \times 0.65 \mathrm{~m}$. The soil was prepared with a plow and then with a disc plow at the $0-20 \mathrm{~cm}$ depth; $8 \mathrm{t} \cdot \mathrm{ha}^{-1}$ of dolomitic limestone and $2 \mathrm{t} \cdot \mathrm{ha}^{-1}$ of agricultural gypsum were applied in the area, as recommended by the Soil Fertility Commission for Minas Gerais (Guimarães et al. 1999).

After soil preparation, Brachiaria ruziziensis was planted in the interrow as a cover crop. The planting furrow was prepared at the depth of $60 \mathrm{~cm}$ and fertilization consisted of application of $980 \mathrm{~kg} \cdot \mathrm{ha}^{-1}$ of NPK (08-44-00) associated with $1.0 \%$ of Zn and $0.5 \%$ of B and topdressing fertilization with $380 \mathrm{~kg} \cdot \mathrm{ha}^{-1}$ of NPK (20-00-20). In the other years, maintenance fertilization was performed according to the technical recommendations for Minas Gerais (Guimarães et al. 1999).

The agricultural gypsum rates for the treatments were applied on the soil surface at four months after planting. They were applied only in the row of the coffee plantation, within a $0.5 \mathrm{~m}$ wide band. Then, with the help of a rear blade attached to a tractor and aligned with the planting row at $45^{\circ}$, the gypsum band was covered with soil from the interrow. Five years after planting the coffee trees and applying the gypsum treatments, soil and root were sampled at different depths in the planting 
Table 1. Chemical characterization of the typical dystrophic red latosol of the experimental area for the treatments with agricultural gypsum rates, in the dry and rainy seasons, at three soil depths, and a native forest area as a reference of the natural soil.

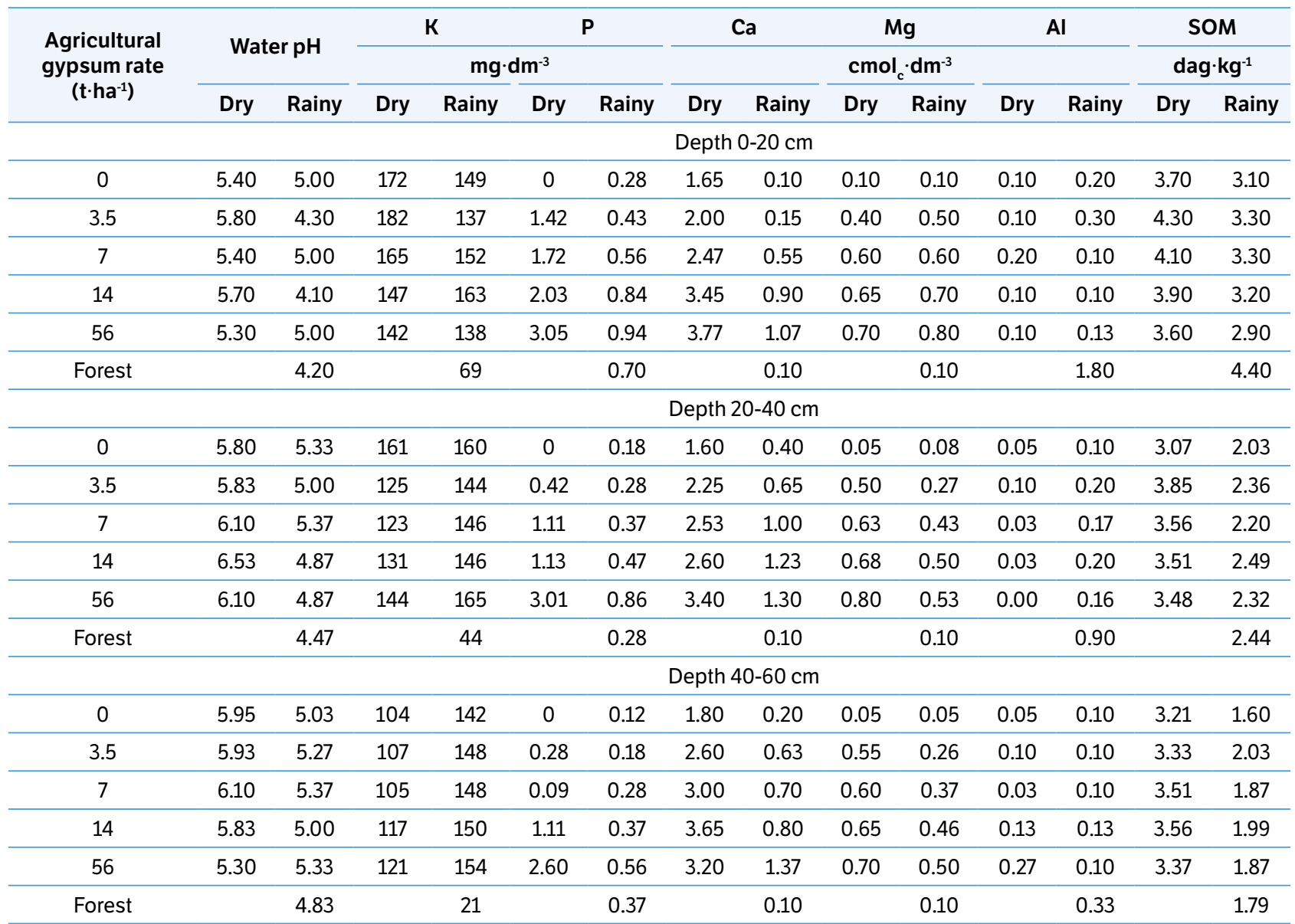

(1) water $\mathrm{pH}, 1: 2: 5$ ratio; $\mathrm{Al}^{3+} ; \mathrm{Mg}^{2+}$ and $\mathrm{Ca}^{2+}$, extracted with $\mathrm{KCl} 1 \mathrm{~mol} \cdot \mathrm{L}^{-1} ; \mathrm{K}$ and $\mathrm{P}$, extracted by Mehlich $\mathrm{I}$ SOM: soil organic matter, oxidized with potassium dichromate in an acid medium.

row of the coffee plantation in two seasons: the first in October 2013 at the end of the cold and dry season (dry period) and the second in May 2014 at the end of the hot and rainy season (rainy period). Table 1 shows the chemical characterization of the soil of the experimental area for the treatments with agricultural gypsum rates, in the dry and rainy seasons, at three depths and in the native forest area.

Arbuscular mycorrhizal fungi spores were extracted from the samples using $50 \mathrm{~g}$ of soil and the wet sieving method (Gerdemann and Nicolson 1963), followed by centrifugation in a sucrose solution (Jenkins 1964). Then, the spores were identified morphologically, based on the descriptions of the AMF species provided in the original works of species description and species descriptions available on the website of the International Culture Collection of Arbuscular and VesicularArbuscular Mycorrhizal Fungi (INVAM 2016).

Assessment of species richness was based on the number of species in each treatment using $50 \mathrm{~mL}$ of soil; species occurrence frequency (OF\%) was calculated using the ratio between number of samples with the presence of the AMF species and total number of samples multiplied by 100; relative density of each AMF species in each treatment was determined by the ratio of number of spores of a given species to total number of spores multiplied by 100 .

The coffee tree roots were separated from the soil, bleached and stained (Koske and Gemma 1989), and the root colonization rate was estimated by the grid method (Giovannetti and Mosse 1980).

For aggregation analysis, soil blocks were collected at the depth of $0-20 \mathrm{~cm}$, previously air dried and sieved in $8.0-$ and $4.0-\mathrm{mm}$ meshes. Then, the aggregates retained in the $4 \mathrm{~mm}$ sieve were transferred to a set of sieves $(\varnothing \geq 2.0,2.0>\varnothing \geq 0.25$ 
and $\varnothing<0.105 \mathrm{~mm}$ ), adapted to a mechanical vibration device (Solo Teste PBX 289-0211SP). The material retained in each sieve was classified as macroaggregates $(\varnothing \geq 2.0 \mathrm{~mm})$, mesoaggregates $(2.0>0 \geq 0.25 \mathrm{~mm})$ and microaggregates $(\varnothing<0.105 \mathrm{~mm})$. A portion of each fraction of aggregates was used to quantify easily extractable glomalin-related soil protein (EE-GRSP), according to the methodology described by Wright and Upadhyaya (1998). For this purpose, $1 \mathrm{~g}$ of each sample, together with $8 \mathrm{~mL}$ of sodium citrate $\left(20 \mathrm{mmol} \cdot \mathrm{L}^{-1}, \mathrm{pH} 7.2\right)$, was autoclaved $\left(121^{\circ} \mathrm{C}\right)$ for $30 \mathrm{~min}$ followed by centrifugation ( $3200 \mathrm{rpm}$ for $20 \mathrm{~min}$ ). Supernatants were quantified with a spectrophotometer through the Bradford method, using standard bovine albumin (Bradford 1976).

Data for correlation with the above-mentioned variables were collected from yield records maintained by the manager of the farm Fazenda AP Família between the years 2011 (1st production) and 2014 (4th production). During 2014, leaves and beans were sampled in the different plots for analysis of $\mathrm{P}$ content.

The data were submitted to tests for error normality and homoscedasticity of variances, respectively, using the ShapiroWilk and Bartlett tests. When these assumptions were not satisfied, the data were transformed by $\log (x+1)$. Then, analysis of variance, Pearson's correlation and comparison of means by the Scott-Knott test at $5 \%$ probability or by regression analysis were performed using Sisvar (Ferreira 2003), "R" (R Development Core Team 2011) and PAST (Hammer et al. 2001).

\section{RESULTS AND DISCUSSION}

In total, six AMF species were found in the study areas. Nine species occurred in the dry season and ten in the rainy season (Table 2). The species Gigaspora sp. and Glomus macrocarpum in the two sampling periods were the species with the highest occurrence frequency (OF\%), as shown by the mean of the two periods in 76 and $26 \%$ of the samples, respectively. The species Acaulospora morrowiae, A. scrobiculata, Glomus sp., Paraglomus occultum, Dentiscutata heterogama, Cetraspora pellucida and Scutellospora sp. presented intermediate OF\% with values ranging between 4 and 20\%. Acaulospora scrobiculata, Glomus sp., Dentiscutata heterogama and Scutellospora sp. occurred in both seasons and the species P. occultum and Cetraspora pellucida occurred only in the rainy season, while A. morrowiae occurred only in the dry season.

The species Acaulospora sp. and Sieverdingia tortuosa (in the rainy season) and Claroideoglomus etunicatum and Rhizophagus intraradices (in the dry season) presented low sporulation in only $2 \%$ of the samples. The species Acaulospora sp., Sieverdingia tortuosa and Claroideoglomus etunicatum were found only in the treatment that received $7 \mathrm{t} \cdot \mathrm{ha}^{-1}$ of agricultural gypsum: the first one at the depth of 0-20 cm and the last two at the depth of $20-40 \mathrm{~cm}$. Rhizophagus intraradices was found only in the treatment with $56 \mathrm{t}^{-h^{-1}}$ of agricultural gypsum at the depth of $40-60 \mathrm{~cm}$.

The highest number of AMF species was found in the area where $7 \mathrm{t} \cdot \mathrm{ha}^{-1}$ had been applied (Table 2); seven species were found in the rainy season while eight were found in the dry season. There was a smaller number of species where higher rates had been applied. At the greatest depth $(40-60 \mathrm{~cm})$, there was reduced richness of AMF species in most of the gypsum rates applied, in both sampled periods.

The results of the present study show that application of up to $7 \mathrm{t}$ of gypsum favors AMF diversity while high rates of gypsum promotes changes and reduction in the arbuscular mycorrhizal fungi community.

Among the AMF species that were recovered, Gigaspora sp. and Glomus macrocarpum showed the highest level of adaptability and survival, regardless of agricultural gypsum rate. Arbuscular mycorrhizal fungi inventories in coffee-growing areas of southeastern Brazil, Colombia and Venezuela showed widespread occurrence of species of the genus Acaulospora, followed by Glomus (Saggin Júnior and Siqueira 1996; Cogo et al. 2017). Species of the genus Glomus and Acaulospora (Arias et al. 2012; Fernandes et al. 2016) are usually predominant in coffee plantations; thus, dominance of species of the genus Gigaspora in coffee fields has not been frequently reported. In a previous study conducted in a greenhouse, the species Gigaspora margarita was found to be one of the most efficient in promoting growth and nutrition of coffee trees (Saggin Júnior and Siqueira 1996). Thus, further research could be conducted on efficiency of the species Gigaspora sp., found to be dominant in the present study, as a species that it adapted to high fertility environments in coffee plantations.

Spore density of the AMF species was not significantly affected by gypsum rates (Table 3 ). In the dry season at rate 0 , spore density ranged from 24 to $84 \mathrm{AMF}$ spores per $\cdot \mathrm{dm}^{-3}$, regardless of depth. It was reduced at high rates, ranging from 11 to $18 \mathrm{AMF}$ 
Table 2. Arbuscular mycorrhizal fungi species community, species richness, occurrence frequency (OF\%) and relative spore density in dry and rainy seasons at the depths of 0-20 (20); 20-40 (40) and 40-60 cm (60) after application of agricultural gypsum (rates of 0,3.5, 7, 14 and $\left.56 \mathrm{t} \cdot \mathrm{ha}^{-1}\right)$ in coffee plantations.

\begin{tabular}{|c|c|c|c|c|c|c|c|c|c|c|c|c|c|c|c|c|c|}
\hline & \multirow{2}{*}{ AMF species } & \multirow{2}{*}{ OF\% } & \multicolumn{3}{|c|}{0} & \multicolumn{3}{|c|}{3.5} & \multicolumn{3}{|c|}{7.0} & \multicolumn{3}{|c|}{14} & \multicolumn{3}{|c|}{56} \\
\hline & & & 20 & 40 & 60 & 20 & 40 & 60 & 20 & 40 & 60 & 20 & 40 & 60 & 20 & 40 & 60 \\
\hline & & \multicolumn{16}{|c|}{ Dry season } \\
\hline 1 & $\begin{array}{l}\text { Acaulospora morrowiae } \\
\text { Spain \& N.C. Schenck }\end{array}$ & 4.44 & & 1.49 & 0.8 & & & & & & & & & & & & \\
\hline 2 & $\begin{array}{c}\text { Acaulospora scrobiculata } \\
\text { Trappe }\end{array}$ & 20.0 & 11.1 & 53.7 & & 26 & & & & 3.13 & 57.4 & & & & 2.63 & 7.89 & \\
\hline 3 & $\begin{array}{l}\text { Claroideoglomus etunicatum } \\
\text { (W.N. Becker \& Gerd.) C. } \\
\text { Walker \& A. Schüßler }\end{array}$ & 2.22 & & & & & & & & 3.13 & & & & & & & \\
\hline 4 & Gigaspora sp. & 86.7 & 51.4 & 44.8 & 99.2 & 10 & 100 & 82.4 & 8.89 & 84.4 & 14.8 & 73.6 & 8.77 & 100 & 96.1 & 92.1 & 95.5 \\
\hline 5 & $\begin{array}{l}\text { Rhizophagus intraradices } \\
\text { (N.C. Schenck \& G.S. Sm.) C. } \\
\text { Walker \& A. Schüßler }\end{array}$ & 2.22 & & & & & & & & & & & & & & & 4.76 \\
\hline 6 & $\begin{array}{l}\text { Glomus macrocarpum Tul. \& } \\
\text { C. Tul. }\end{array}$ & 24.4 & 37.5 & & & 62 & & & 68.9 & 9 & 25.9 & 26.4 & & & 1.32 & & \\
\hline 7 & Glomus sp. & 8.89 & & & & 2 & & & & & 1.85 & & 86 & & & & \\
\hline 8 & $\begin{array}{l}\text { Dentiscutata heterogama } \\
\text { (T.H. Nicolson \& Gerd.) } \\
\text { Sieverd., F.A. Souza \& Oehl }\end{array}$ & 4.44 & & & & & & 17.6 & 15.6 & & & & & & & & \\
\hline \multirow[t]{4}{*}{9} & Scutellospora sp. & 4.44 & & & & & & & 6.67 & & & & 5.3 & & & & \\
\hline & $\begin{array}{l}\text { Richness by depth within the } \\
\text { rate }\end{array}$ & & 3 & 3 & 2 & 4 & 1 & 2 & 4 & 4 & 4 & 2 & 3 & 1 & 3 & 2 & 2 \\
\hline & $\begin{array}{l}\text { Richness per agricultural } \\
\text { gypsum rate }\end{array}$ & & & 4 & & & 5 & & & 7 & & & 4 & & & 4 & \\
\hline & & \multicolumn{16}{|c|}{ Rainy season } \\
\hline 1 & $\begin{array}{c}\text { Acaulospora scrobiculata } \\
\text { Trappe }\end{array}$ & 11.1 & & & 79.5 & 51.3 & 37.5 & & & 76.2 & & & & & & & \\
\hline 2 & Acaulospora sp. & 1.85 & & & & & & & 3.85 & & & & & & & & \\
\hline 3 & Gigaspora sp. & 64.8 & 33.3 & 85.7 & 18.2 & 15.4 & 54.2 & 90.9 & 7.69 & 5.95 & 85.7 & & 100 & 43 & 22.2 & 40 & 33.3 \\
\hline 4 & $\begin{array}{c}\text { Glomus macrocarpum Tul. \& } \\
\text { C. Tul. * }\end{array}$ & 27.8 & 5.56 & & & & 8.33 & & & 8.33 & 14.3 & 44.4 & & & 77.8 & 40 & \\
\hline 5 & Glomus sp.* & 13.0 & 50 & & 2.27 & & & 9.09 & & & & 22.2 & & & & & 11.1 \\
\hline 6 & $\begin{array}{l}\text { Sieverdingia tortuosa (N.C. } \\
\text { Schenck \& G.S. Sm.) Błaszk., } \\
\text { Niezgoda \& B.T. Goto }\end{array}$ & 1.85 & & & & & & & 3.85 & & & & & & & & \\
\hline 7 & $\begin{array}{l}\text { Paraglomus occultum (C. } \\
\text { Walker) J.B. Morton \& D. } \\
\text { Redecker }\end{array}$ & 3.70 & 5.56 & & & & & & & & & 11.1 & & & & & \\
\hline 8 & $\begin{array}{l}\text { Dentiscutata heterogama } \\
\text { (T.H. Nicolson \& Gerd.) } \\
\text { Sieverd., F.A. Souza \& Oehl }\end{array}$ & 11.1 & & 14.3 & & & & & 80.8 & & & 11.1 & & & & & \\
\hline 9 & $\begin{array}{l}\text { Cetraspora pellucida (T.H. } \\
\text { Nicolson \& N.C. Schenck) } \\
\text { Oehl, F.A. Souza \& Sieverd. }\end{array}$ & 9.26 & & & & 33.3 & & & & 9.52 & & & & 57 & & 20 & 22.2 \\
\hline 10 & Scutellospora sp. & 7.41 & 5.56 & & & & & & 3.85 & & & 11.1 & & & & & 33.3 \\
\hline & $\begin{array}{l}\text { Richness by depth } \\
\text { within the rate }\end{array}$ & & 5 & 2 & 3 & 3 & 3 & 2 & 5 & 4 & 2 & 5 & 1 & 2 & 2 & 2 & 4 \\
\hline & $\begin{array}{l}\text { Richness per agricultural } \\
\text { gypsum rate }\end{array}$ & & & 7 & & & 5 & & & 8 & & & 6 & & & 5 & \\
\hline
\end{tabular}

*Species found in the native forest sampled as a reference of the natural soil in the rainy season. Acaulospora morrowiae Spain \& NC Schencke and Acaulospora spinosa $\mathrm{C}$. Walker \& Trappe were added to the species with an asterisk. 
spores per $\cdot \mathrm{dm}^{-3}$. In comparison, this did not occur in the rainy season, in which density ranged from 3 to $28 \mathrm{AMF}$ spores per $\cdot \mathrm{dm}^{-3}$, without significant differences between the study treatments $(\mathrm{p} \leq 0.05)$. The fact that spore density of AMF species has not been significantly affected by the treatments is due to biotic and abiotic factors that interfere with induction of sporulation of different AMF species; for example, vegetative stage of the host plant, edaphic and climatic factors (Oliveira and Oliveira 2010), addition of organic compounds (Yang et al. 2018) and seasonal sporulation of the different AMF species (Escudero and Mendoza 2005). In the present study, there was great variability of spore density, particularly in the rainy season, and reduced sporulation in the dry season, indicating that climate and season had a stronger effect on AMF sporulation than the study treatments.

There was an effect of gypsum rates, depth and interaction between gypsum rates and depth on mycorrhizal colonization in the two sampled seasons. However, the results were inconsistent and there was no clear trend of the best rate between the different depths and sampling times (Table 3). In general, mycorrhizal colonization was high in the coffee plantation, with values ranging from 25 to $68 \%$, at all depths and in both seasons.

In the dry season, mycorrhizal colonization of the roots was decreased as application rate and depth were increased. In the rainy season, colonization was reduced at higher depths $(40-60 \mathrm{~cm})$. This suggests that such modification at deeper layers caused by high gypsum rates may reduce mycorrhizal colonization, and such reduction may have been caused by increased phosphorus availability in deeper layers (Table 1), since P available in the deeper layers was higher in the dry season. This is due to the widely known fact that mycorrhizal colonization of coffee trees is reduced with increased soil P availability (Siqueira et al. 1994; 1998).

Easily EE-GRSP was affected by gypsum application rates and by depth only in the rainy season (Fig. 1). Extracted glomalinrelated soil protein contents decreased linearly with increased agricultural gypsum rates (Fig. 1a) and increased with depth (Fig. 1b). The analysis of EE-GRSP within aggregate-size classes showed an effect of such classes in both periods in a comparison of macroaggregates $(\varnothing>2.0 \mathrm{~mm})$ with higher levels of EE-GRSP to mesoaggregates $(2.0>\varnothing \geq 0.25 \mathrm{~mm})$ and microaggregates (Fig. 2).

(a)

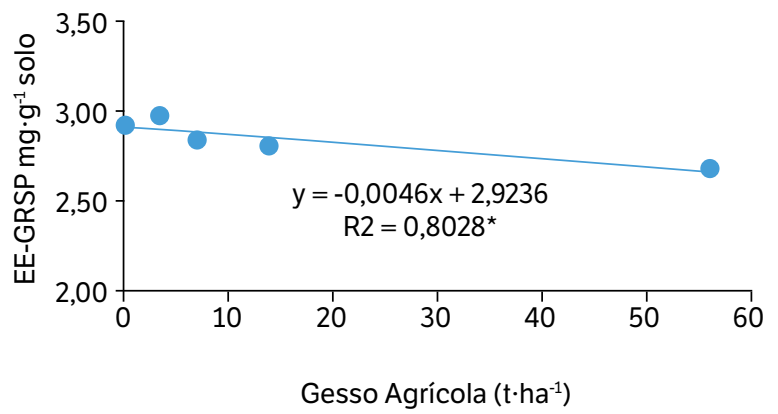

(b)

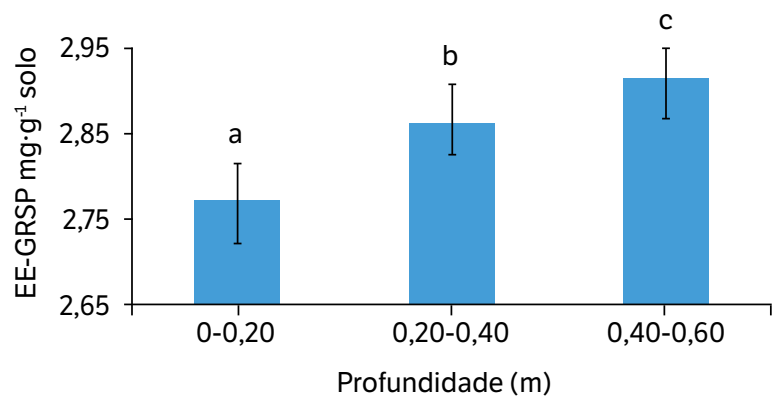

Figure 1. Easily extractable glomalin-related soil protein (EE-GRSP) on the basis of agricultural gypsum rates (a) and sampling depths (b) at the end of the rainy season (May 2014).

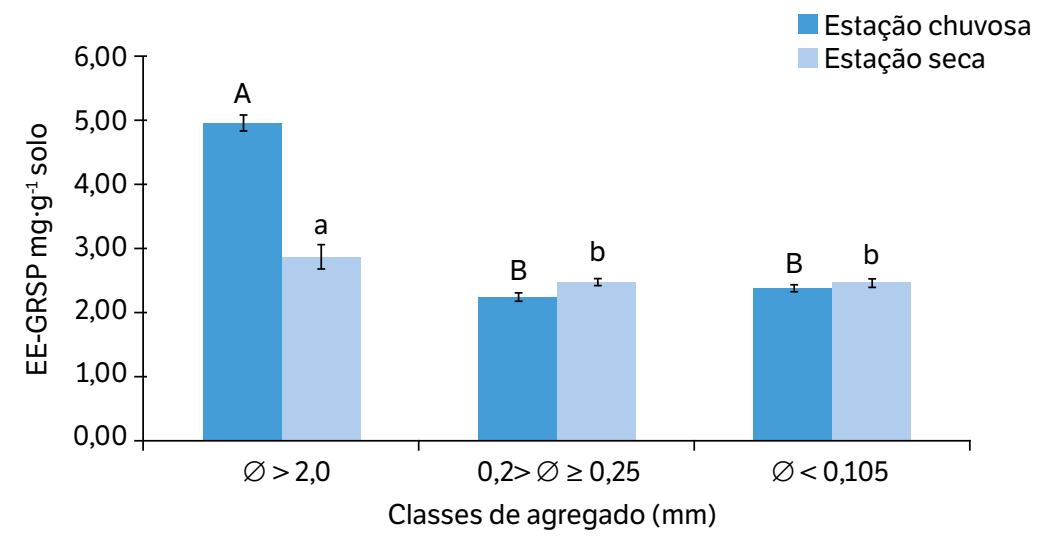

Figure 2. Easily extractable glomalin-related soil protein (EE-GRSP) in soil aggregates within the classes of macroaggregates $(\emptyset>2.0 \mathrm{~mm})$, mesoaggregates $(0.2>\emptyset \geq 0.25 \mathrm{~mm})$ and microaggregates $(\varnothing<0.105 \mathrm{~mm})$ at the end of the dry season (October 2013) and rainy season (May 2014$)$. 
The increase of EE-GRSP in deeper soil layers in the rainy season (Fig. 1B) may be due to root deepening resulting from the effect of gypsum. These studies do not corroborate the findings of Wu et al. (2012), who found that glomalin decreases at higher depths. However, these authors have shown that glomalin correlates positively with presence of roots and carbohydrates in the soil. In the present study, gypsum promoted root deepening and led to mycorrhizal colonization in the rainy season (Fig. 1B).

Wu et al. (2012) found that glomalin correlates positively with $\beta$-glucosidase enzymes but negatively with proteases. Oxidized proteins (in more oxygenated environments) are more susceptible to breakdown by proteases (Starke-Reed and Oliver 1989), which can reduce decomposition of glomalin in deeper layers in the rainy season while increasing its release from within the cellulosic structures of the cells. This corroborates the results of the present study.

Extracted glomalin-related soil protein values decreased from 2.98 to $2.68 \mathrm{mg} \cdot \mathrm{g}^{-1}$ because of gypsum rates in the rainy season (Fig. 1A). Although there was a reduction of only $0.30 \mathrm{mg} \cdot \mathrm{g}^{1}$, these values are similar to those found in the forest area $\left(2.72 \mathrm{~g} \cdot \mathrm{mg}^{-1}\right)$. These results show that EE-GRSP levels are very sensitive to use and management of soil (Bai et al. 2011). In other words, the reduction of the highest gypsum rate to $2.68 \mathrm{mg} \cdot \mathrm{g}^{-1}$ indicates a lower value than that of the forest, suggesting a stress response to the AMF community, because in the other treatments with gypsum rates lower than $56 \mathrm{t} \cdot \mathrm{ha}^{-1}$, EE-GRSP levels were above the reference value (forest). Therefore, the highest gypsum rate not only decreased the diversity of the AMF community and reduced mycorrhizal colonization in deeper soil layers, as discussed above, but also possibly reduced the biomass of the AMF community (extraradical hyphae) and, consequently, reduced glomalin production. On the other hand, conversion of native forest to agricultural production systems generally reduces glomalin content (Bai et al. 2011; Fernandes et al. 2016), which did not happen in the present study at most gypsum rates. This is indicative that the application of agricultural gypsum up to the rate of $14 \mathrm{t}^{\cdot} \cdot \mathrm{ha}^{-1}$ in coffee plantations promotes a sustainable environment from the point of view of the AMF community.

The higher EE-GRSP content in macroaggregates than in mesoaggregates and microaggregates (Fig. 2) is a common effect (Vilela et al. 2014) that was not modified by gypsum rates. The physical effect of extraradical hyphae of approximating soil particles to form macroaggregates, results in a greater release of glomalin, which acts as a cementing and stabilizing agent in macroaggregates.

Table 4 shows coffee yield on the basis of gypsum application rates between 2011 and 2014, cumulative yield in this period and $\mathrm{P}$ content in the beans and leaves in 2014. In the first production (2011), gypsum application in the coffee plantation rows practically doubled yield in comparison to the control without gypsum. However, this effect was not maintained in yield results of the following years. In the years 2012 and 2013 and in cumulative yield between 2011-2014, there was a quadratic adjustment of the means, with yield increasing up to 14 tons $\cdot \mathrm{ha}^{-1}$. Phosphorus levels in beans and leaves also had a quadratic adjustment, presenting only the upward side of the parabola in the study rates, that is, both levels increased after agricultural gypsum application in the coffee plantation.

Table 3. Mycorrhizal colonization of coffee tree roots in the dry and rainy seasons, at the depths of 0-20 (20); 20-40 (40) and 40-60 cm (60), after application of agricultural gypsum rates in the coffee plantation.

\begin{tabular}{|c|c|c|c|c|c|c|c|c|c|c|c|c|c|c|c|c|c|c|}
\hline \multirow{2}{*}{$\begin{array}{l}\text { Gypsum rate } \\
\left(\mathrm{t} \cdot \mathrm{ha}^{-1}\right)\end{array}$} & \multicolumn{9}{|c|}{ Dry season } & \multicolumn{9}{|c|}{ Rainy season } \\
\hline & \multicolumn{3}{|c|}{20} & \multicolumn{3}{|c|}{40} & \multicolumn{3}{|c|}{60} & \multicolumn{3}{|c|}{20} & \multicolumn{3}{|c|}{40} & \multicolumn{3}{|c|}{60} \\
\hline & \multicolumn{18}{|c|}{ Mycorrhizal colonization (\%) } \\
\hline 0 & 49 & a & $A$ & 31 & $\mathrm{~b}$ & B & 43 & $\mathrm{~b}$ & A & 35 & c & C & 58 & a & $A$ & 42 & $\mathrm{~b}$ & B \\
\hline 3.5 & 53 & a & A & 40 & a & B & 53 & a & $A$ & 53 & $\mathrm{~b}$ & A & 53 & $b$ & $A$ & 49 & a & A \\
\hline 7 & 46 & a & A & 25 & $b$ & B & 41 & b & A & 50 & $\mathrm{~b}$ & A & 46 & c & $A$ & 45 & $b$ & A \\
\hline 14 & 58 & a & $A$ & 43 & $a$ & B & 34 & c & B & 53 & $\mathrm{~b}$ & B & 58 & a & $A$ & 52 & a & B \\
\hline 56 & 50 & a & A & 46 & $a$ & $A$ & 30 & c & B & 68 & $a$ & A & 50 & $b$ & B & 44 & $b$ & C \\
\hline Regression adjustment & NA & & & NA & & & NA & & & NA & & & NA & & & NA & & \\
\hline
\end{tabular}

NA: no significant regression adjustment. *Means followed by the same letter, lowercase in the column and uppercase in the row, do not differ statistically by the Scott-Knott test at $5 \%$ probability of error. 
Table 4. Yield from 2011 to 2014 and P content in beans and leaves in 2014 in coffee trees after application of agricultural gypsum rates.

\begin{tabular}{|c|c|c|c|c|c|c|c|}
\hline \multirow{2}{*}{$\begin{array}{c}\text { Gypsum rates } \\
\left(t \cdot h a^{-1}\right)\end{array}$} & \multicolumn{5}{|c|}{ Yield } & \multicolumn{2}{|c|}{ P content } \\
\hline & 2011 & 2012 & 2013 & 2014 & $\begin{array}{l}\text { Cumulative } \\
2011-2014\end{array}$ & Beans & Leaves \\
\hline & \multicolumn{5}{|c|}{ Sacks·ha-1 } & \multicolumn{2}{|c|}{$\mathrm{g} \cdot \mathrm{kg}^{-1}$} \\
\hline 0.0 & 25.3 & 52.6 & 69.2 & 91.1 & 238 & 1.77 & 0.10 \\
\hline 3.5 & 49.5 & 57.2 & 85.6 & 71.2 & 263 & 1.75 & 0.10 \\
\hline 7.0 & 43.9 & 65.2 & 75.5 & 57.5 & 242 & 1.77 & 0.10 \\
\hline 14.0 & 50.3 & 71.5 & 90.7 & 87.1 & 300 & 1.82 & 0.10 \\
\hline 56.0 & 45.0 & 67.4 & 65.4 & 77.4 & 255 & 1.84 & 0.12 \\
\hline Regression & SA & $\begin{array}{c}y=52.4 \\
+1.78 x \\
-0.027 x^{2}\end{array}$ & $\begin{array}{c}y=72.0 \\
+1.69 x \\
-0.032 x^{2}\end{array}$ & $\mathrm{SA}$ & $\begin{array}{c}y=235.6 \\
+4.97 x \\
-0.082 x^{2}\end{array}$ & $\begin{array}{c}y=1.75 \\
+5.09 E-03 x \\
-6.2 E-05 x^{2}\end{array}$ & $\begin{array}{c}y=0.10 \\
-1.37 E-04 x \\
-9.71 E-06 x^{2}\end{array}$ \\
\hline $\mathrm{R}^{2}$ & - & 0.98 & 0.74 & - & 0.65 & 0.82 & 1.00 \\
\hline
\end{tabular}

NA: No significant regression adjustment.

Coffee yield reflects the same trend observed in the AMF community (Table 5), indicating that the rate of 56 ha $^{-1}$ of agricultural gypsum is excessive and affects yield, and also reduces the diversity of the AMF community and EE-GRSP. The higher gypsum rate increases $\mathrm{P}$ content in the coffee beans and leaves, which is a consequence of residual phosphorus present in the agricultural gypsum. The increase in available phosphorus in the whole soil profile, caused by the gypsum rates (Table 1), certainly has a role in reducing the FMA community, because there is a well-known effect of reducing the need of plants to maintain symbiosis after an increase in P availability (Smith et al. 2011), which ends up causing harm to the present AMF community.

\section{CONCLUSION}

The application of high rates of gypsum $\left(56 \mathrm{t} \cdot \mathrm{ha}^{-1}\right)$ negatively affected density and diversity of AMF, as it reduced mycorrhizal colonization, glomalin levels and coffee yield.

Gypsum application between 7 and $14 \mathrm{t} \cdot \mathrm{ha}^{-1}$ did not affect AMF diversity. Gigaspora sp. and Glomus macrocarpum were the dominant species in all situations.

\section{ACKNOWLEDGMENTS}

The authors are grateful to the Brazilian Consortium for Coffee Research and Development (CBP\&D/Café) and to the employees of the farm Fazenda AP Família, Piumhi- MG, who contributed to the accomplishment of this work.

\section{FUNDERS}

Coordenação de Aperfeiçoamento de Pessoal de Nível Superior (Doctoral scholarship)

Conselho Nacional de Desenvolvimento Científico e Tecnológico

Grant \# 310947/ \#2017-0

Fundação de Amparo à Pesquisa do Estado de Minas Gerais

Grant \# APQ-01661-16 


\section{AUTHOR'S CONTRIBUTION}

Conceptualization: Cogo F. D. and Carneiro M.A.C; Methodology and Investigation: Cogo F. D.; Writing - Original Draft: Cogo F. D. and Carneiro M.A.C.; Writing - Review and Editing: Saggin Junior O. J.: Guimarães P. T. G. and Siqueira J. O.; Funding Acquisition and Supervision: Carneiro M. A. C.

\section{REFERENCES}

[INVAM] International culture collection of arbuscular and vesicular-arbuscular mycorrhizal fungi. west Virginia University. [Accessed Jan. 12, 2016]. Available at: http://invam.caf.wva.edu

Alban, R., Guerrero, R. and Toro, M. (2013). Interactions between a root knot nematode (Meloidogyne exigua) and arbuscular mycorrhizae in coffee plant development (Coffea arabica). American Journal of Plant Sciences, 4, 19-23. https://doi.org/10.4236/ajps.2013.47A2003

Arias, R. M., Heredia-Abarca, G., Sosa, V. J. and Fuentes-Ramírez, L. E. (2012). Diversity and abundance of arbuscular mycorrhizal fungi spores under different coffee production systems and in a tropical montane cloud forest patch in Veracruz, Mexico. Agroforestry Systems, 85, 179-193. https://doi.org/10.1007/s10457-011-9414-3

Bai, H., Bao, X., Sun, X., Jiang, X., Bai, H. and Bao, X. (2011). The effect of stocking rate on soil glomalin under traditional and mixed grazing systems in a temperate steppe. Procedia Environmental Sciences, 11, 817-823. https://doi.org/10.1016/j.proenv.2011.12.125

Bradford, M. M. (1976). A rapid and sensitive method for the quantitation of microgram quantities of protein utilizing the principle of protein-dye binding. Analytical Biochemistry, 72, 248-254. https://doi.org/10.1016/0003-2697(76)90527-3

Carducci, C. E., Oliveira, G. C., Curi, N., Heck, R. J., Rossoni, D. F., Carvalho, T. S. and Costa, A. L. (2015). Gypsum effects on the spatial distribution of coffee roots and the pores system in oxidic Brazilian Latosol. Soil \& Tillage Research, 145, 171-180. https://doi.org/10.1016/j. still.2014.09.015

Carneiro, M. A. C., Ferreira, D. A., Souza, E. D., Paulino, H. B., Saggin Júnior, O. J. and Siqueira, J. O. (2015). Arbuscular mycorrhizal fungi in soil aggregates from fields of "murundus" converted to agriculture. Pesquisa Agropecuária Brasileira, 50, 313-321. https://doi. org/10.1590/S0100-204X2015000400007

Climate-Data.Org. (2019). Dados climáticos para cidades mundiais: São Roque de Minas [Internet]. [Accessed Fev. 25, 2019]. Available at: https://pt.climate-data.org/america-do-sul/brasil/minas-gerais/sao-roque-de-minas-24975/

Cogo, F. D., Guimarães, P. T. G., Rojas, E. P., Saggin Júnior, O. J., Siqueira, J. O. and Carneiro, M. A. C. (2017). Arbuscular mycorrhiza in Coffea Arabica L.: review and meta-analysis. Coffee Science, 12, 419-443. https://doi.org/10.25186/cs.v12i3.1227

Escudero, V. and Mendoza, R. (2005). Seasonal variation of arbuscular mycorrhizal fungi in temperate grasslands along a wide hydrologic gradient. Mycorrhiza, 15, 291-299. https://doi.org/10.1007/s00572-004-0332-3

Fernandes, R. A., Ferreira, D. A., Saggin Junior, O. J., Stürmer, S. L., Paulino, H. B., Siqueira, J. O. and Carneiro, M. A. C. (2016). Occurrence and species richness of mycorrhizal fungi in soil under different land use. Canadian Journal of Soil Science, 96, 271-280. https://doi. org/10.1139/cjss-2015-0011

Ferreira, D. F. (2003). SISVAR 5.0: sistema de análises estatísticas. Lavras: UFLA.

França, A. C., Freitas, A. F., Santos, E. A., Grazziotti, P. H. and Andrade Júnior, V. C. (2016). Mycorrhizal fungi increase coffee plants competitiveness against Bidens pilosa interference. Pesquisa Agropecuária Tropical, 46, 132-139. https://doi.org/10.1590/1983-40632016v4639485

Gerdemann, J. W. and Nicolson, T. H. (1963). Spores of mycorrhizal Endogone species extracted from soil by wet sieving and decanting. Transactions of the British Mycological Society, 46, 235-244. https://doi.org/10.1016/S0007-1536(63)80079-0 
Giovannetti, M. and Mosse, B. (1980). An evaluation of techniques to measure vesicular-arbuscular mycorrhizal infection in roots. New Phytologisty, 84, 489-500. https://doi.org/10.1111/j.1469-8137.1980.tb04556.x

Guimarães, P. T. G., Garcia, A. W. R., Alvarez, V. H., Prezotti, L. C., Viana, A. S., Miguel, A. E., Malavolta, E., Corrêa, J. B., Lopes, A. S., Nogueira, F. D., Monteiro, A. V. C. and Oliveira, J. A. (1999). Cafeeiro. In A. C. Ribeiro, P. T. G. Guimarães and V. H. Alvares (Eds.), Recomendações para o uso de corretivos e fertilizantes em Minas Gerais. $5^{a}$ aproximação. (p. 289-302). Viçosa: CFSEMG.

Hammer, Ф., Harper, D. A. T. and Ryan, P. D. (2001). Past: Paleontological statistics software package for education and data analysis. Palaeontologia Electronica, 4, 1-9.

Jenkins, W. R. (1964). A rapid centrifugal-flotation technique for separating nematodes from soil. Plant Disease Report, $48,692$.

Koske, R. E. and Gemma, J. N. (1989). A modified procedure for staining roots to detect VA mycorrhizas. Mycological Research, 92, 486488. https://doi.org/10.1016/S0953-7562(89)80195-9

Lopes, A. S. and Cox, F. R. (1977). A survey of the fertility status of surface soils under "Cerrado" vegetation in Brazil. Soil Science Society of America Journal, 41, 742-747. https://doi.org/10.2136/sssaj1977.03615995004100040026x

Moreira, S. D., França, A. C., Rocha, W. W., Tibães, E. S. R. and Neiva Júnior, E. (2018). Inoculation with mycorrhizal fungi on the growth and tolerance to water deficit of coffee plants. Revista Brasileira de Engenharia Agrícola e Ambiental, 22, 747-752. https://doi.org/10.1590/18071929/agriambi.v22n11p747-752

Oliveira, A. N. and Oliveira, L. A. (2010). Influence of edapho-climatic factors on the sporulation and colonization of arbuscular mycorrhizal fungi in two Amazonian native fruit species. Brazilian Archives of Biology and Technology, 53, 653-661. https://doi.org/10.1590/ S1516-89132010000300021

R Development Core Team. (2011). R: A language and environment for statistical computing. Vienna: R Foundation for Statistical Computing. http://www.r-project.org/

Ramos, B. Z., Toledo, J. P. V. F., Lima, J. M., Serafim, M. E., Bastos, A. R. R., Guimarães, P. T. G. and Coscione, A. R. (2013). Doses de gesso em cafeeiro: influência nos teores de cálcio, magnésio, potássio e pH na solução de um latossolo vermelho distrófico. Revista Brasileira de Ciência do Solo, 37, 1018-1026. https://doi.org/10.1590/S0100-06832013000400019

Saggin Júnior, O. J. and Siqueira, J. O. (1996). Micorrizas arbusculares em cafeeiro. In J. O. Siqueira (Ed.), Avanços em fundamentos e aplicação de micorrizas (p. 203-254). Lavras: Universidade de Lavras/DCS e DCF.

Saggin Júnior, O. J., Siqueira, J. O., Guimarães, P. T. G. and Oliveira, E. (1994). Interação fungos micorrízicos versus superfosfato e seus efeitos no crescimento e teores de nutrientes do cafeeiro em solo não fumigado. Revista Brasileira de Ciência do Solo, $18,27-36$.

Santos, H. G., Jacomine, P. K. T., Anjos, L. H. C., Oliveira, V. A., Oliveira, J. B., Coelho, M. R., Lumbreras, J. F. and Cunha, T. J. F. (2006). Centro Nacional de Pesquisa de Solos. Sistema Brasileiro de Classificação de Solos. Rio de Janeiro: Embrapa-SPI. [Accessed Mar. 8 2017]. Available at: https://www.agrolink.com.br/downloads/sistema-brasileiro-de-classificacao-dos-solos2006.pdf

Serafim, M. E., Oliveira, G. C., Oliveira, A. S., Lima, J. M., Guimarães, P. T. G. and Costa, J. C. (2011). Sistema conservacionista e de manejo intensivo do solo no cultivo de cafeeiros na região do Alto São Francisco, MG: estudo de caso. Bioscience Journal, 27, 964-977.

Silva, É. A., Oliveira, G. C., Silva, B. M., Carducci, C. E., Avanzi, J. C. and Serafim, M. E. (2014). Aggregate stability by the "high energy moisture characteristic" method in an oxisol under differentiated management. Revista Brasileira de Ciência do Solo, $38,1633-1642$. https://doi.org/10.1590/S0100-06832014000500028

Siqueira, J. O., Colozzi Filho, A. and Saggin Júnior, O. J. (1994). Efeitos da infecção de plântulas de cafeeiro com quantidades crescentes de esporos do fungo endomicorrízico Gigaspora margarita. Pesquisa Agropecuária Brasileira, 29, 875-883.

Siqueira, J. O., Saggin-Júnior, O. J., Flores-Aylas, W. W. and Guimarães, P. T. G. (1998). Arbuscular mycorrhizal inoculation and superphosphate application influence plant development and yield of coffee in Brazil. Mycorrhiza, 7, 293-300. https://doi.org/10.1007/s005720050195 
Smith, S. E., Jakobsen, I., Grønlund, M. and Smith, F. A. (2011). Roles of arbuscular mycorrhizas in plant phosphorus nutrition: Interactions between pathways of phosphorus uptake in arbuscular mycorrhizal roots have important implications for understanding and manipulating plant phosphorus acquisition. Plant Physiology, 156, 1050-1057. https://doi.org/10.1104/pp.111.174581

Starke-Reed, P. E. and Oliver, C. N. (1989). Protein oxidation and proteolysis during aging and oxidative stress. Archives of Biochemistry and Biophysics, 275, 559-567. https://doi.org/10.1016/0003-9861(89)90402-5

Vilela, L. A. F., Saggin Júnior, O. J., Paulino, H. B., Siqueira, J. O., Santos, V. L. D. S. and Carneiro, M. A. C. (2014). Arbuscular mycorrhizal fungus in microbial activity and aggregation of a Cerrado Oxisol in crop sequence. Ciência e Agrotecnologia, 38, 34-42. https://doi. org/10.1590/S1413-70542014000100004

Wright, S. F. and Upadhyaya, A. (1998). A survey of soils for aggregate stability and glomalin, a glycoprotein produced by hyphae of arbuscular mycorrhizal fungi. Plant Soil, 198, 97-107. https://doi.org/10.1023/A:1004347701584

Wu, Q.-S., He, X.-H., Zou, Y.-N., He, K.-P., Sun, Y.-H. and Cao, M.-Q. (2012). Spatial distribution of glomalin-related soil protein and its relationships with root mycorrhization, soil aggregates, carbohydrates, activity of protease and $\beta$-glucosidase in the rhizosphere of Citrus unshiu. Soil Biology and Biochemistry, 45, 181-183. https://doi.org/10.1016/j.soilbio.2011.10.002

Yang, W., Gu, S., Xin, Y., Bello, A., Sun, W. and Xu, X. (2018). Compost addition enhanced hyphal growth and sporulation of arbuscular mycorrhizal fungi without affecting their community composition in the soil. Frontiers in Microbiology, 9, 169. https://doi.org/10.3389/ fmicb.2018.00169

In the article High rates of agricultural gypsum affect the arbuscular mycorrhiza fungal community and coffee yield with DOI: https://doi.org/10.1590/1678-4499.20200014, published in Bragantia vol.79 no.4 Campinas Oct./Dec. 2020:

In the footline where is read Bragantia, Campinas, v. 79, n. 4, p.487-497, 2020 should be read Bragantia, Campinas, v. 79, n. 4, p.612-622, 2020. 